\title{
Physiological differences between coexisting congeneric species of snails in a subarctic lake
}

\author{
Katherine S. Arakelova ${ }^{1, *}$, Ellinor Michel ${ }^{2}$ \\ ${ }^{1}$ Zoological Institute of RAS, 1 Universitetskaya emb., St. Petersburg 199034, Russia \\ ${ }^{2}$ Department of Zoology, The Natural History Museum, Cromwell Road, London SW7 5BD, UK
}

\begin{abstract}
Quantitative measures of feeding, respiration, growth and reproduction were brought together to achieve an overview of differences in physiology between 2 sympatric species of Anisus (Gastropoda, Planorbidae) in subarctic Lake Krivoye, northwestern Russia. This is a resource-limited lake with a short summer growing season where one might expect intense competition for resources among the numerous snails. Because coexistence is a multidimensional process, we have aimed to quantify bioenergetic variables related to several different major physiological functions. Using experiments that manipulated detritus and periphyton, we showed that both species consume detritus in combination with algae, but used different feeding strategies. Anisus contortus has a steeper growth allometry, greater specific growth rate and faster reproductive cycle. Anisus acronicus, however, has a faster absolute growth rate and longer life cycle, which results in its dominance in biomass and numbers. Although bioenergetics in general cannot be used to test directly for competition between closely related species, we have shown alternative growth and energy-metabolism strategies used by different species in a common habitat. Indicators of niche partitioning, maintained by balance calculations, included differences in preferences, quality and consumption rate of consumed food. We expect that these differences are not only important in proximal coexistence, but may also present alternatives for surviving long-term changes in the lake's productivity and habitat types.
\end{abstract}

KEY WORDS: Anisus contortus - Anisus acronicus - Coexistence - Subarctic lake · Respiration · Growth $\cdot$ Feeding $\cdot P / B$ coefficients

\section{INTRODUCTION}

Freshwater communities commonly include coexisting congeneric species. When resources are limiting and competition plays a role, coexistence requires limiting similarity with neighboring species to ensure ecological separation (Tilman 1994). This can happen through partitioning of food and habitat resources by selective feeding, habitat specificity or staggered life cycles (Townsend \& Hildrew 1979, Williams 1994) and should be reflected in differences in the species autecology. A number of classic ecological studies are devoted to determining how resources are partitioned along niche axes among coexisting species (Underwood 1984, Fletcher \& Creese 1985, Schmitt 1996, Yu et al. 2003), guilds (Hines 1982), or populations (Wenngren \& Ólafsson 2002).
We tested hypotheses of trophic and metabolic separation for the snails Anisus (Bathyomphalus) contortus (Linnaeus, 1758) and A. (Gyraulus) acronicus (Férussac, 1807) (=Gyraulus gredleri [Bielz] Gredler, 1853) (Gastropoda, Planorbidae) which co-exist in Lake Krivoye in northwestern Russia. This is a resourcelimited lake with a short growing season where one might expect intense competition for resources. The snails are broadly sympatric in habitat occurrence. Because coexistence is a multidimensional process, connected with spatial distribution, demographics, external resources and specific ecological differences between species, we have aimed to quantify major bioenergetic variables with a focus on feeding, but also address respiration, growth and fecundity.

Feeding, ingestion, absorption and egestion rates are the central variables determining the input and output 
of an animal's bioenergetics. Selectivity in feeding can result in resource partitioning (Schoener 1974) and results from either adaptive specializations that are species- or population-specific, or from behavioral plasticity that allows animals to cope with variation in food types in space and time. Several studies have quantified ingestion rates and absorption efficiencies in freshwater gastropods, such as Calow's (1975) work on differences between the grazers Ancylus fluviatilis (Müller, 1774) and detritivores Planorbis (Anisus) contortus (Linnaeus, 1758), Eleutheriadis \& LazaridouDimitriadou's (1996) work on Bithynia graeca (Westerlund 1879), Brendelberger's (1997) work on Radix peregra (Müller, 1774) and B. tentaculata (Linnaeus, 1758) and Lombardo \& Cooke's (2004) study of consumption rates in 2 co-occuring species, Physa sp. and Helisoma trivolvis (Say, 1817).

The rate of food consumption in detritus-feeding invertebrates is controlled by the animal's energetic needs and is generally inversely proportional to the food quality (Cammen 1979, McIntyre et al. 2005). In snails considered to be algivores, the relative consumption of periphyton and detritus material has seldom been compared directly (Lombardo \& Cooke 2002). Absorption, the most significant quantitative indicator of nutrition, allows us to trace the transformation of utilized food and to characterize distinctive features of the ecology of coexisting species. As for other physiological functions, the absorption rate depends primarily on the animal's mass. Quantitative data on absorption rates are comparatively limited to the welldocumented relationships between respiration, growth rate and animal size. Food absorption of target species and the biomass of competitors may be used as a measure of competitive advantage (Basset 1997). There are currently sufficient published data related to growth and metabolism of macroinvertebrates providing us with a common notion about the mean rate of absorption.

Life history differences among species are commonly explained as a balance between the demands for growth and reproduction (Stearns 1992). Differences in growth rates are common among closely related species that divide ecological space. For example, 2 closely related sympatric Heleobia species showed different growth rates along a gradient of estuarine conditions (De Francesco \& Isla 2004). Lymnaea peregra and L. ovata have convergent adult forms despite differing genetics; however, when grown under the same conditions they differed in juvenile growth rate and reproductive schedule (Wullschleger \& Jokela 2002). Differences in size among closely related species that share a habitat may be evidence of genetic differences that determine alternative life history strategies, i.e. different balances of growth and fecundity. Quantitative descriptions of growth curves are generally focused on changes in mass through time, but should also include ontogenetic events such as attainment of reproductive maturity, onset of senescence and total life span. The aim of the present study was to measure the rates of the main physiological processes in 2 freshwater planorbid snails. We bring together quantitative measures of respiration, growth and feeding to achieve an overview of potential bioenergetic differences between 2 sympatric Anisus species. We use these results to assess whether coexistence is mediated by quantitative differences in life history and physiology, especially feeding, among species.

\section{MATERIALS AND METHODS}

Study site and species size. This research was carried out in the oligotrophic Lake Krivoye situated in the basin of the White Sea, northwestern Russia. The surface area of this lake does not exceed $0.5 \mathrm{~km}^{2}$, the maximal depth is $\sim 30 \mathrm{~m}$ and mean depth is $11.8 \mathrm{~m}$. Ice covers the surface from October to late May and mean temperatures range from 16 to $17^{\circ} \mathrm{C}$ during the growing season. The aquatic macrophytes Potamogeton crispus L., Phragmites communis Trin., the sedge Carex leporina $\mathrm{L}$. and other reeds occur, but only rarely, in the narrow strip of littoral zone.

Anisus contortus and A. acronicus (Fig. 1) samples were collected in a single sampling effort from 2 shallow littoral sites where they are broadly sympatric at depths of 0 to $0.5 \mathrm{~m}$. The sites were $1 \mathrm{~km}$ apart and chosen to differ in flow regime and substrates. Site 1 $\left(66^{\circ} 20^{\prime} 16.96^{\prime \prime} \mathrm{N} ; 33^{\circ} 38^{\prime} 50.42^{\prime \prime} \mathrm{E}\right)$ had continuous water flow as it was situated at the head of an out-flowing stream and snails occurred on stones and pebbles, the preferred substrate for both species. Potamogeton sp. occurred at Site 1 , but only rarely. Site $2\left(66^{\circ} 20^{\prime}\right.$

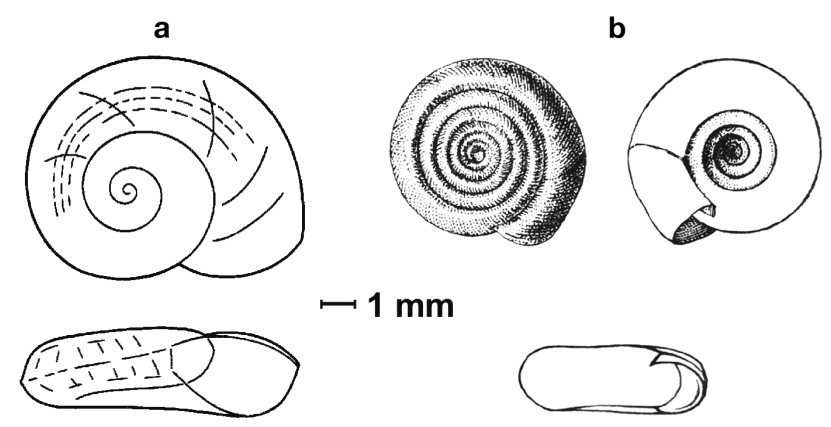

Fig. 1. Anisus acronicus and A. contortus. (a) A. acronicus apical and apertural views (redrawn from Starobogatov 1977, Fig. 414a,b). (b) Anisus contortus apical (left), basal and apertural views (redrawn from Zhadin 1952, Fig. 93) 
38.21" $\mathrm{N}^{\prime} 33^{\circ} 38^{\prime} 00.03^{\prime \prime} \mathrm{E}$ ) had still water, and the snail substrate included the common reed Phragmites communis. To quantify the relative abundances and biomass of snails at each site, we sampled with a $25 \times$ $25 \mathrm{~cm}$ square frame placed randomly over 4 sections of the bottom at each site. The sampling frame was fastened on 3 corners and could be opened on the 4th corner as needed to encompass macrophytes within the quadrat area. The upper layer of the sediment, pebbles, small stones and macrophytes were removed from the bottom by hand, and all snails were collected, counted and measured.

Size-weight allometry was calculated with the standard equation:

$$
W=a L^{b}
$$

where $W$ is the wet weight of snails in $\mathrm{mg}, L$ is the length of the longest shell diameter in $\mathrm{mm}, a$ and $b$ are the allometric coefficients.

Energy content $\left(\mathrm{J} \mathrm{mg}^{-1}\right)$ was determined by bichromate oxidation for organic material found in whole animal body and shell tissue, eggs, algae, detritus and faeces (Ostapenja 1965).

Respiration experiments. Oxygen consumption rates were determined in situ using closed bottles designed for measurements of zooplankton respiration (Edmondson \& Winberg 1971) with volumes and exposure times adjusted for the study of macroinvertebrates. Snails of known total wet weight (5 to $65 \mathrm{mg}$ ) were placed individually into ground glass-stoppered 18 to $35 \mathrm{ml}$ flasks (depending on snail size) with filtered lake water. The control with 3 replicates was immediately titrated using the Winkler method for initial oxygen concentration. Experiments were designed so that the oxygen content in the flasks during testing did not decrease to below $25 \%$ of the initial value. To comply with this condition, the experiments ran for 3 to $8 \mathrm{~h}$ depending on flask volume, snail size and temperature. To calculate respiration rates, the titration value of each experimental flask was corrected for changes in the final control and subtracted from the average of the initial controls. The relationship between standard energy metabolism, $R$, and body mass, was expressed as:

$$
R=a W^{b}
$$

where $R$ is the rate of oxygen consumption $\left(\mathrm{ml} \mathrm{O}_{2} \mathrm{~h}^{-1}\right)$ and $W$ is the wet mass (mg). Conversion of $R$ values in $\mathrm{ml} \mathrm{O}_{2} \mathrm{~h}^{-1}$ to $\mathrm{J} \mathrm{d}^{-1}$ was made by using the coefficient 20.307 $\mathrm{J} \mathrm{ml} \mathrm{O}_{2}^{-1}$.

Growth experiments. Growth experiments were carried out in the laboratory over 1 mo of observation. After weighing and measuring, 5 to 10 snails of similar sizes were placed in $200 \mathrm{ml}$ beakers $(\mathrm{n}=13)$ with filtered lake water which had a neutral $\mathrm{pH}(7.4 \pm 0.4)$ at ambient lab temperatures $\left(17\right.$ to $\left.22^{\circ} \mathrm{C}\right)$. Snails (39 ind. in total) were matched for shell size and mass (Table 1). Container volume was large compared to biomass and unlikely to have inhibited growth. Food was added in excess to prevent negative effects of grouping on growth rate. In a parallel experiment, single snails $(n=20)$ were put in the beakers of the same volume to allow us to quantify individual growth increments and test for grouping effects in the first experiment. The natural substrates such as macrophyte remnants and algae-covered pebbles from the original collection site were added to the beakers as food. The water and food source were changed every $3 \mathrm{~d}$. Shell size and snail weight were recorded every 3 to $5 \mathrm{~d}$ for young individuals, and every 10 to $15 \mathrm{~d}$ for mature animals.

Growth was estimated based on shell length (taken as maximum diameter on these planispiral snails) and body weight increments. The von Bertalanffy function was used:

$$
L_{t}=L_{\infty}\left\{1-\exp \left[\left(t-t_{0}\right)(-k)\right]\right\}
$$

where $k$ is a growth constant, $L_{\infty}$ is the maximum shell diameter and $L_{t}$ is the diameter at age $t$ at the midpoint of any day. The growth constant $k$, parameter $L_{\infty}$ and life span $T_{\max }$ were estimated graphically (Walford 1946, Alimov 1989). The instantaneous growth rate $\mathrm{d} w / \mathrm{d} t$, considered to be the individual production $P$, was estimated as $P=C_{W} W$, where $C_{W}$ is the specific growth rate at each $t$ depending on $k$ :

$$
C_{W}=(\mathrm{d} W / \mathrm{d} t) / W=\left(b k \mathrm{e}^{-k t}\right) /\left(1-\mathrm{e}^{-k t}\right)
$$

where $b$ is the allometric coefficient from Eq. (1).

\begin{tabular}{|c|c|c|c|c|}
\hline Experiment & $\begin{array}{c}\text { No. } \\
\text { con- } \\
\text { tainers }\end{array}$ & $\begin{array}{l}\text { No. ind. } \\
\text { per con- } \\
\text { tainer }\end{array}$ & $\begin{array}{l}\text { Shell size } \\
\text { Mean } \pm \text { SE } \\
(\mathrm{mm})\end{array}$ & $\begin{array}{l}\text { Weight } \\
\text { Mean } \pm \text { SE } \\
(\mathrm{mg})\end{array}$ \\
\hline \multicolumn{5}{|l|}{ Growth } \\
\hline \multirow[t]{4}{*}{ A. acronicus } & 3 & 10 & $5.2 \pm 0.2$ & $21.8 \pm 1.8$ \\
\hline & 3 & 6 & $5.8 \pm 0.7$ & $27.7 \pm 7.1$ \\
\hline & 3 & 5 & $7.7 \pm 0.5$ & $50.2 \pm 7.7$ \\
\hline & 10 & 1 & $3.1-8.6^{\mathrm{a}}$ & $7.3-63.5^{\mathrm{a}}$ \\
\hline \multirow[t]{3}{*}{ A. contortus } & 2 & 10 & $3.2 \pm 0.3$ & $7.3 \pm 1.8$ \\
\hline & 2 & 8 & $4.9 \pm 0.4$ & $22.3 \pm 4.8$ \\
\hline & 10 & 1 & $2.6-5.2^{\mathrm{a}}$ & $4.2-26.0^{\mathrm{a}}$ \\
\hline \multicolumn{5}{|l|}{ Feeding } \\
\hline \multicolumn{5}{|c|}{ Epipelic periphyton } \\
\hline A. acronicus & 12 & $4-13$ & $4.6-6.6^{\mathrm{a}}$ & $16.8-36.2^{\mathrm{a}}$ \\
\hline A. contortus & 12 & $5-15$ & $2.0-4.6^{\mathrm{a}}$ & $2.1-18.9^{\mathrm{a}}$ \\
\hline \multicolumn{5}{|c|}{ Algae grown on glass } \\
\hline A. acronicus & 12 & $3-8$ & $6.8-8.2^{\mathrm{a}}$ & $38.6-57.4^{\mathrm{a}}$ \\
\hline A. contortus & 12 & $8-12$ & $3.0-5.1^{\mathrm{a}}$ & $6.2-24.7^{\mathrm{a}}$ \\
\hline
\end{tabular}

Table 1. Anisus acronicus and A. contortus. Experimental setup and size and weights of the snails in growth and feeding

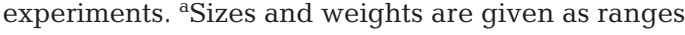


Feeding experiments. Feeding experiments with loose detritus $(\mathrm{n}=24)$ and periphyton $(\mathrm{n}=24)$ were carried out in order to approximate the different food quality available to animals in the field (Table 1). Freshly collected snails were placed in $200 \mathrm{ml}$ beakers with the 2 categories of food added beforehand. Loose food consisted of detrital sediments with epilithic algae washed off the submerged stones. This was sieved $(1.5 \mathrm{~mm}$ mesh), diluted in filtered lake water and added in equal volumes $(\sim 30 \mathrm{ml})$ into control and experimental beakers brought to a total volume of $100 \mathrm{ml}$ with water. Following the model shown below, food absorption $(A)$ was defined as: $\left[C_{\text {final }}\right]=\left[C_{\text {initial }}\right]-C+F$ or $C-F=A=$ $\left[C_{\text {initial }}\right]-\left[C_{\text {final }}\right]$, where $\left[C_{\text {initial }}\right]$ and $\left[C_{\text {final }}\right]$ are food concentrations in the control and at the end of the experiment, $C$ is food consumed and $F$ is faeces. The concentration of food was determined as the caloric content of the sediment suspension (with and without faeces) settled onto previously combusted and weighed Whatman glass-fiber filters GF/C $(\varnothing=35 \mathrm{~mm})$ in equal volumes for control and trials. Depending on food quality, this volume varied from 10 to $30 \mathrm{ml}$. The bio-energetic absorption efficiency coefficient, $a$, was estimated as the ratio between the absorption $(A)$, determined by the formula $A=C-F$, and consumption $(C)$.

The attached food for grazing was provided by growing periphyton in situ on $2.5 \times 7.5 \mathrm{~cm}$ glass slides suspended vertically in $20 \mathrm{~cm}$ water depth in the zone of Potamogeton sp. In each trial, 2 algae-covered slides were placed vertically into a container so that snails could graze both sides, providing a total grazable area of $75 \mathrm{~cm}^{2}$. Freshly caught snails ( $\mathrm{n}=3$ to 15 ) were placed in the experimental beakers and allowed to graze during 2 trials of 5 and $7 \mathrm{~h}$ each. Faecal pellets were gathered throughout the experiment by pipette and laid onto the filter paper pad covered by a nylon sieve with a mesh diameter of $56 \mu \mathrm{m}$. Dried pellets were weighed and subjected to bichromate oxidation to determine caloric content. Any remaining unconsumed algae was scraped off into the water and passed through the filters in equal volumes $\left(10 \mathrm{ml} \mathrm{l}^{-1}\right)$ to determine dry mass and caloric content in $\mathrm{J}$ (Whatman GF/F filters, $\mathrm{n}=3$ ). Food consumption $(C)$ was determined as the difference between mass of periphyton on glass slides in control (without snails) and experimental containers.

\section{RESULTS}

Shell length and individual body weight revealed different size-weight allometries between the 2 species ( $t$-test, length: $t$ [10.63], $\mathrm{p}=1.82 \mathrm{E}-17$; weight: $t$ [8.83], $\mathrm{p}=2.19 \mathrm{E}-13$ ) (Fig. 2):
A. contortus: $W=0.346 L^{2.62}\left(\mathrm{n}=68, \mathrm{r}^{2}=0.94\right)$

A. acronicus: $W=0.663 L^{2.12}\left(\mathrm{n}=54, \mathrm{r}^{2}=0.97\right)$

The mean caloric value of both species (with shell) was $11.3 \pm 1.3 \mathrm{~kJ} \mathrm{~g}^{-1}$ dry weight or $3.35 \mathrm{~kJ} \mathrm{~g}^{-1}$ wet weight. The shell weight within the range of middle sizes in both species was equal to $30 \pm 3 \%(n=10)$ of whole live weight.

The biomass of Anisus acronicus was greater than that of $A$. contortus at the 2 surveyed sites. The abundance and size distributions of each species differed by site as well (Fig. 3).

Power equations were used for the relationship between the oxygen consumption rate and snail weight of each species:

A. contortus: $R=0.0006 W^{0.641}\left(\mathrm{n}=26, \mathrm{r}^{2}=0.71\right)$

A. acronicus: $R=0.00026 W^{0.846}\left(\mathrm{n}=24, \mathrm{r}^{2}=0.71\right)$

These regressions did not differ significantly in coefficients $b_{1}$ and $b_{2}$ ( $t$-test, $t=1.41, \mathrm{p}=0.01$ ) (Fig. 4). As a result, we derived a common equation for the relationship of oxygen consumption rate and mass:

$$
R=0.0005 W^{0.694}\left(\mathrm{n}=50, \mathrm{r}^{2}=0.72\right)
$$

which we used in further calculations.

\section{Growth}

Absolute growth rate as a function of individual snail weight is approximated by exponential or parabolic equations only on the postembryonic and juvenile stages of growth. Because the absolute growth rate is reduced in snails reaching maturity, we can use Wal-

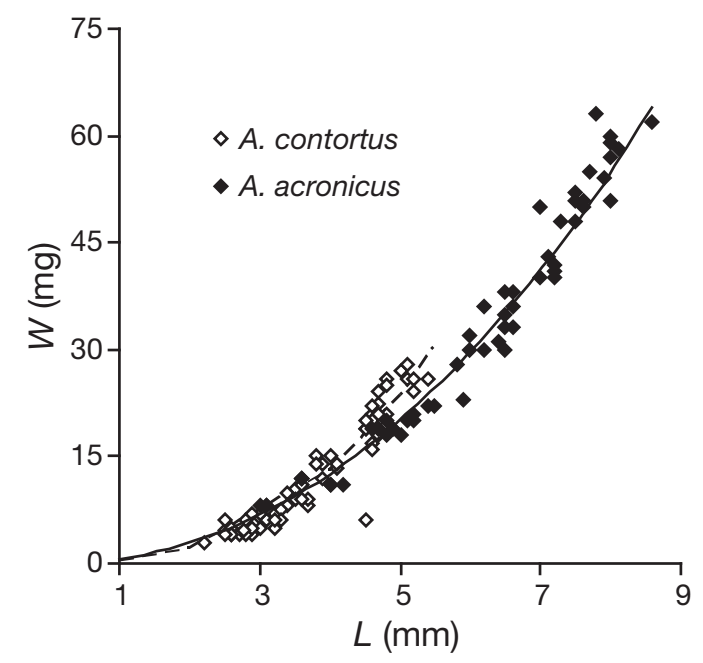

Fig. 2. Anisus contortus and A. acronicus. Relationship between shell length $(L)$ and weight $(W)$. Samples are from both study sites. Trend lines correspond to regression equations given for each species in the text 

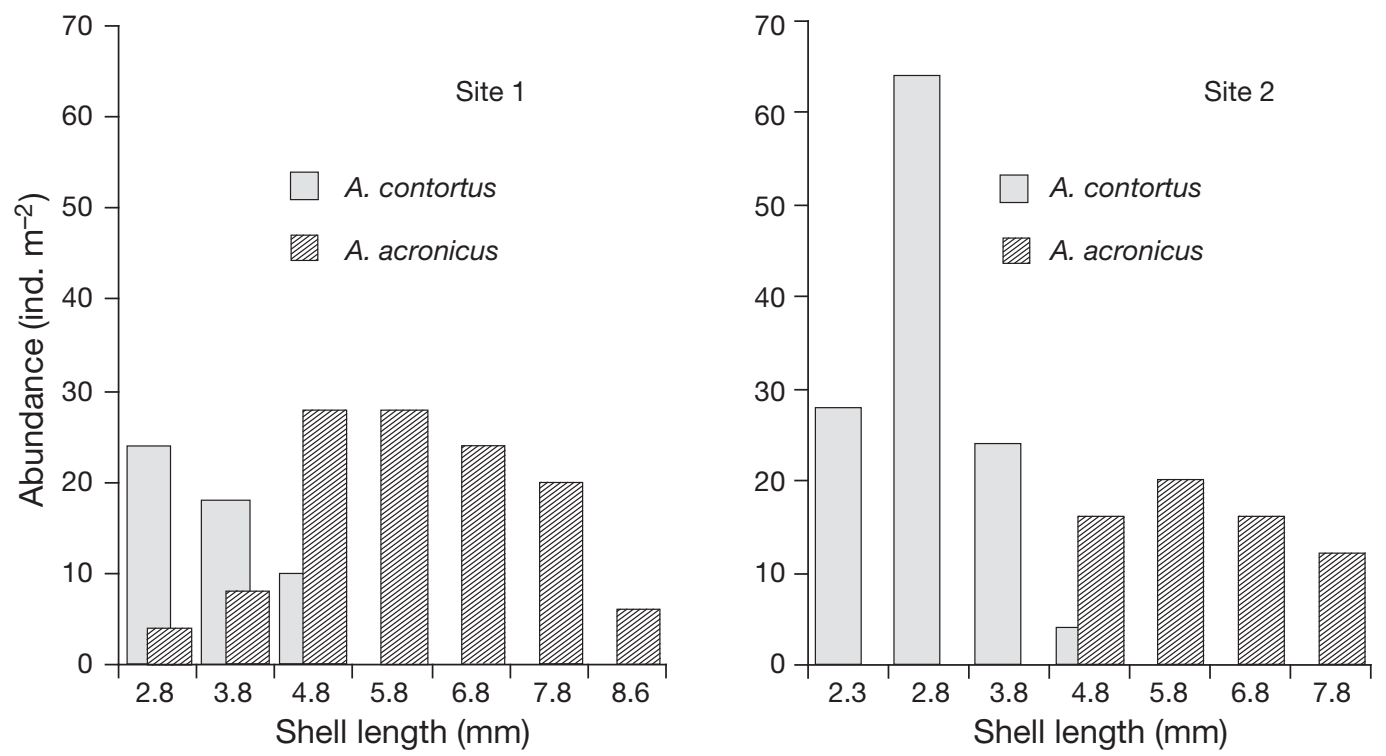

Fig. 3. Anisus contortus and A. acronicus. Size-frequency distribution of A. contortus and A. acronicus by site in early summer 1995

ford's method for computing the parameters of von Bertalanffy's equation (Fig. 5). The following equations were obtained:

A. contortus: $L_{t+4}=0.569+0.896 L_{t}\left(\mathrm{n}=6, \mathrm{r}^{2}=0.98\right)(10)$

A. acronicus: $L_{t+4}=0.499+0.951 L_{t}\left(\mathrm{n}=8, \mathrm{r}^{2}=0.99\right)(11)$

Allometric relationships from linear equations were used for the calculation of growth equations between weight and length of each species:

A. contortus: $W_{t}=33.1\left[1-\mathrm{e}^{-0.026\left(t-t_{0}\right)}\right]^{2.62}$

A. acronicus: $W_{t}=91.1\left[1-\mathrm{e}^{-0.013\left(t-t_{0}\right)}\right]^{2.12}$

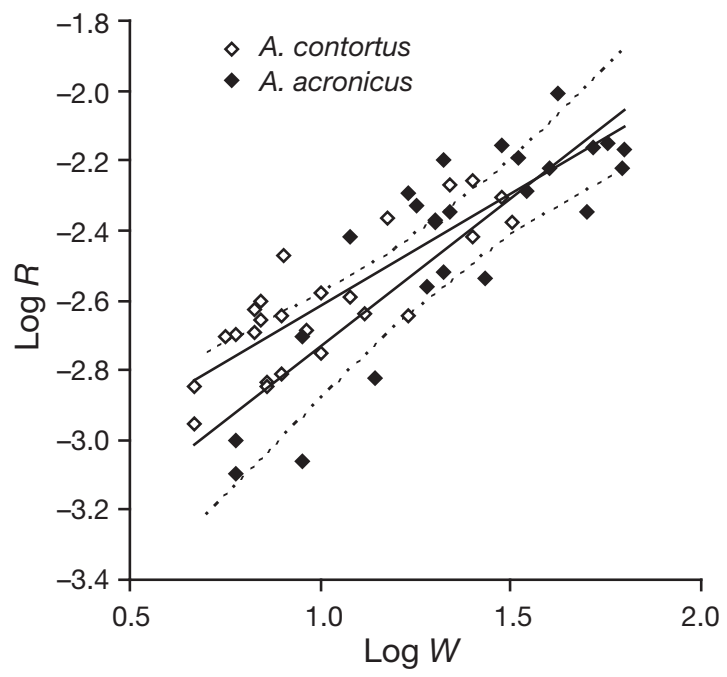

Fig. 4. Anisus contortus and A. acronicus. Relationships between respiration rate $(R)$ and weight $(W)$ for $A$. contortus and A. acronicus at $20^{\circ} \mathrm{C}$. Data are log-transformed. (solid lines): regression lines conforming to Eqs. (7) \& (8); (broken lines): confidence level $(p=0.01)$ for $A$. acronicus where $t_{0}$ is the duration of embryonic development. For both species $t_{0}$ is $15 \mathrm{~d}$ at $20^{\circ} \mathrm{C}$. The predicted maximum value for the life cycle at $20^{\circ} \mathrm{C}$ (the mean temperature used during our growth experiments) was $129 \mathrm{~d}$ for Anisus contortus and $213 \mathrm{~d}$ for A. acronicus. However, in their natural environment, where temperatures are generally lower and often fluctuate, both species have an annual life cycle.

Weight-specific daily growth rates $\left(C_{W}, \mathrm{~d}^{-1}\right)$ defined from Eq. (4) were used for calculating the individual production $(P)$ of snails in terms of the daily increase of weight:

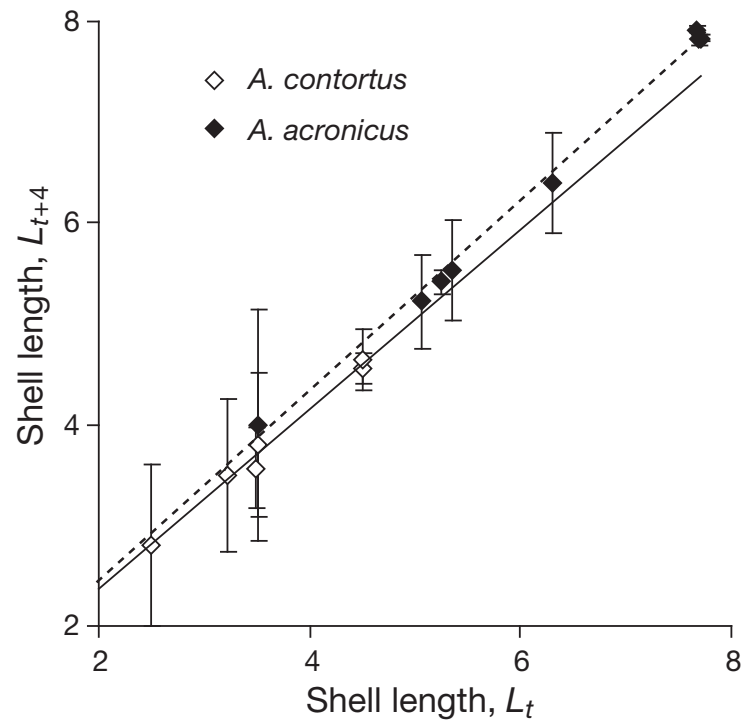

Fig. 5. Anisus contortus and A. acronicus. Growth in laboratory of $A$. contortus and $A$. acronicus. Linear relationship between length $(L, \mathrm{~mm})$ of snails at time $t$ and $t+4 \mathrm{~d}( \pm \mathrm{SE})$ 
A. contortus:

$P=\left[\left(2.62 \times 0.026 \mathrm{e}^{-0.026 t}\right) /\left(1-\mathrm{e}^{-0.026 t}\right)\right] W \times 3.35 \mathrm{~J} \mathrm{~d}^{-1}$

A. acronicus:

$P=\left[\left(2.12 \times 0.013 \mathrm{e}^{-0.013 t}\right) /\left(1-\mathrm{e}^{-0.013 t}\right)\right] W \times 3.35 \mathrm{~J} \mathrm{~d}^{-1}$

In feeding experiments, the caloric content of periphyton and detritus were $5.02 \pm 1.26(\mathrm{n}=6)$ and $3.77 \pm$ $1.67 \mathrm{~J} \mathrm{mg}^{-1}$ dry weight $(\mathrm{n}=6)$, respectively. The relationship between the intensity of feeding $\left(C / W, \mathrm{~J} \mathrm{mg}^{-1}\right.$ $\mathrm{d}^{-1}$ ) and individual mass $(W)$ in the experiment with alga-covered slides was expressed by power equations. For the laboratory grazing experiments (Fig. 6), we obtained the following relationships:

A. contortus:

$C / W=5.494 W^{-0.717}\left(\mathrm{n}=12, \mathrm{r}^{2}=0.471, \mathrm{p}<0.05\right)$

A. acronicus:

$C / W=6.861 W^{-0.74}\left(\mathrm{n}=12, \mathrm{r}^{2}=0.673, \mathrm{p}<0.05\right)$

The regression coefficients of these equations were not significantly different $(t[1.14], \mathrm{p}<0.05)$. Therefore the data were combined and a common equation for both species was used for further calculations:

$$
C / W=5.024 W^{-0.661}\left(\mathrm{n}=24, \mathrm{r}^{2}=0.631, \mathrm{p}<0.05\right)
$$

To calculate the coefficient of absorption efficiency $(a)$, the energy of daily egestion rate $\left(F, \mathrm{~J}_{\text {ind }} .^{-1} \mathrm{~d}^{-1}\right)$ and daily consumption rate, the same average mass of snails from Eq. (18) were used in the formula $a=(C-F)$ $C^{-1}$. The energy content of dried faeces was $3.77 \pm$

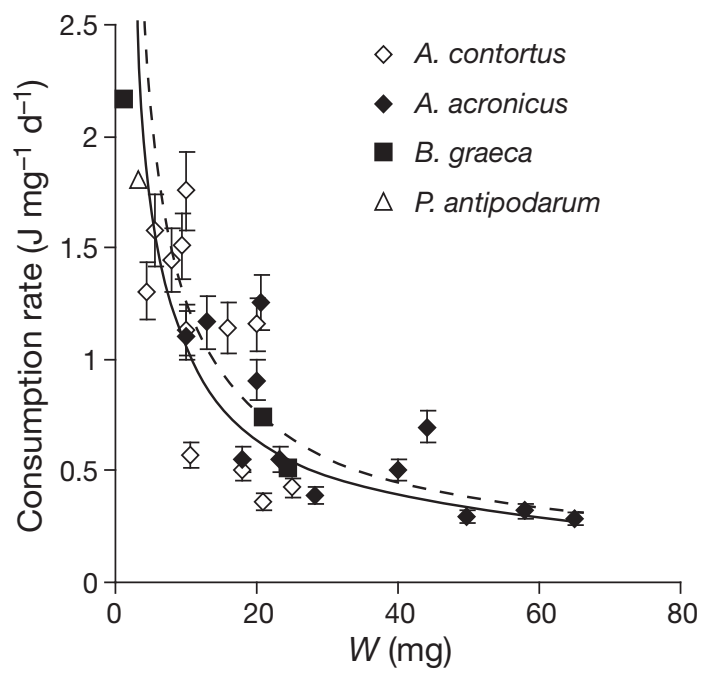

Fig. 6. Anisus contortus, A. acronicus, Bithynia graeca and Potamopyrgus antipodarum. Relationship between specific consumption rate and weight $(W)$ for $A$. contortus and $A$. acronicus fed on algae-covered glass slides in a laboratory experiment. Data for B. graeca and P. antipodarum come from studies by Eleutheriadis \& Lazaridou-Dimitriadou (1996) and James et al. (2000), respectively. Regression lines plotted correspond to Eqs. (16) \& (17). Vertical bars denote range of values for 3 reiterations at filtration $( \pm \mathrm{SE})$

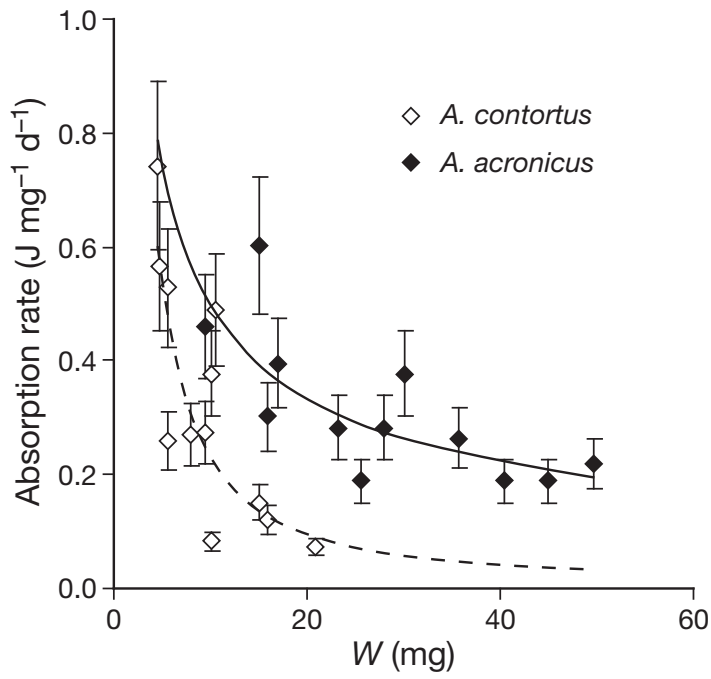

Fig. 7. Anisus contortus and A. acronicus. Relationship between specific absorption rate and weight $(W)$ in $A$. contortus and $A$. acronicus fed on detritus. Regression lines plotted for each of species correspond to Eqs. (19) \& (20). Vertical bars denote the range of values for 3 reiterations at filtration $( \pm \mathrm{SE})$

$1.26 \mathrm{~J} \mathrm{mg}^{-1}$ for both species. The values of absorption efficiency coefficients obtained were $0.57 \pm 0.15$ for Anisus contortus and $0.32 \pm 0.22$ for A. acronicus. The absorption of consumed algae was calculated by multiplying the snails' ration by absorption efficiency coefficients 0.57 and 0.32 for $A$. contortus and A. acronicus, respectively.

In the feeding experiment with loose detritus, absorption was defined empirically (Fig. 7), and the equations of the relationship between the daily specific absorption rate $\left(A / W, \mathrm{~J} \mathrm{mg}^{-1} \mathrm{~d}^{-1}\right)$ and weight of snails $(W)$ were calculated:

$$
\begin{aligned}
& \text { A. contortus: } \\
& A / W=3.87 W^{-1.24}\left(\mathrm{n}=12, \mathrm{r}^{2}=0.63, \mathrm{p}<0.05\right)
\end{aligned}
$$

A. acronicus:

$$
A / W=1.88 W^{-0.58}\left(\mathrm{n}=12, \mathrm{r}^{2}=0.60, \mathrm{p}<0.05\right)
$$

A Student's $t$-test for independent samples used to compare regression lines showed significant differences between allometric coefficients, $b(t$ [5.47], p < 0.05).

\section{DISCUSSION}

Differences in life history and metabolic variables were found for the sympatric snails Anisus acronicus and $A$. contortus. Fine-scale differences in ecology and feeding traits pointing to partial niche overlap, and interspecific competition may be crucial in explaining coexistence between these species in resource-limited systems (Den Boer 1985). Even among closely related 
species, interspecific interactions can involve exploitation or interference of the common space or resources (Schoener 1974, Quiring \& McNeil 1984). Both of our focal species are widely distributed (Zhadin 1952) and are commonly sympatric (Økland 1990), although some microhabitat separation may be evident.

Size and growth variables differed between the 2 species. Anisus acronicus are twice the size of A. contortus in shell length and wet weight. This is achieved more slowly and through a longer life span (for A. contortus, $k=0.026 \mathrm{~d}^{-1}$ and for $A$. acronicus, $k=0.013 \mathrm{~d}^{-1}$ ). In respiration, the regression of $A$. contortus revealed a stronger relationship of intensity of energy metabolism to weight, which changes during growth, than was the case for $A$. acronicus. This suggests that the specific respiration rate must be provided for with food reserves.

We suggest that juveniles of both species meet their metabolic demands by intensive feeding on bacterial detritus, but that for adults there is a trophic shift to aufwuchs. Calow (1975) showed that freshwater snails can selectively consume bacteria and utilize them with very high effectiveness exceeding $90 \%$ in a laboratory setting; however, Underwood \& Thomas (1990) indicated that in the field, the biomass of epiphytic bacteria potentially available to grazing snails may be relatively small, and probably only a small proportion of that is ingested. As Hall \& Meyer (1998) showed, bacterial carbon is important in freshwater systems, and for many taxa of stream insects the fraction of bacterial carbon exceeds $20 \%$. However, the elevated signal of bacterial carbon could be a consequence of the availability of colloidal carbohydrates, which are 5 times greater than bacterial biomass. Freshwater snails may benefit from accessibility of such food, although there is no evidence that they may consume the exudates of bacteria, as shown for some marine bivalves (Amouroux 1984).

The reason we propose a trophic shift is that our calculations show that the empirical absorption is insufficient if its value is lower than the minimum energy required for supporting growth and respiration. Experiments with an algae and detritus complex showed that the energy needed to meet the metabolic demands of the snails could not always be obtained from these diets (Fig. 8). In Eqs. (19) \& (20) the coefficients for weight indicate that the intensity of absorption decreased with the increase in snail weight much more rapidly in Anisus contortus than in A. acronicus. This indicates that $A$. contortus consumes detritus more than it needs only when it is a juvenile. In contrast, experiments with algae grown on glass slides showed that the absorbed part of rations calculated from Eq. (18) exceeds the energy requirements of $A$. contortus by more than double (Fig. 8). This supports the

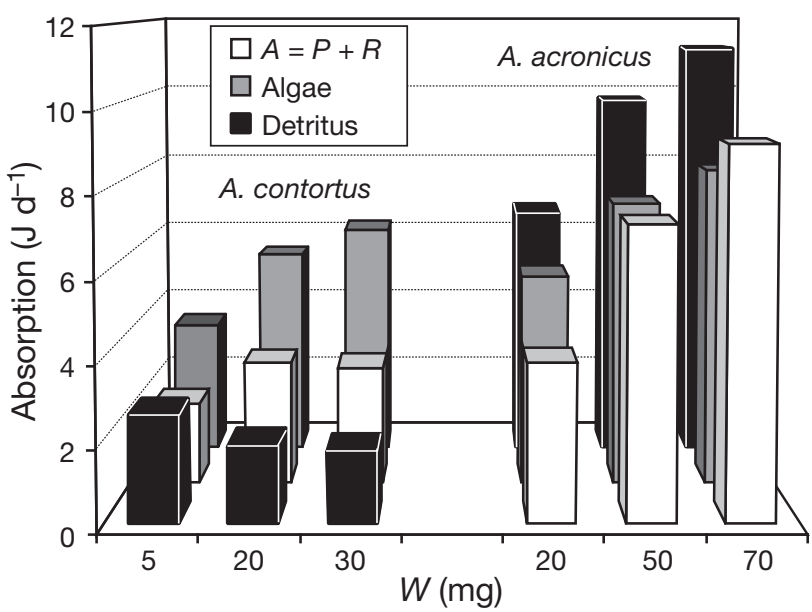

Fig. 8. Anisus contortus and A. acronicus. Absorption of algae and detritus in A. contortus and A. acronicus of different mass $(W)$. Grey columns represent the calculations of absorption of periphyton resulting from Eq. (18). Black columns correspond to Eqs. (19) \& (20). White columns show the minimal level needed for supporting standard level of snail metabolism. Daily energy needed for growth and respiration $(P+R$, respectively) is provided completely (or in excess) by algae for A. contortus and by detritus for A. acronicus

suggestion that juveniles born early in the season grow by consuming bacterial detritus and later switch to algal aufwuchs. In Lake Kirvoye, A. contortus dwell on submerged vegetation, feeding on sediments and periphyton. Natural diatom assemblages, in contrast to epipelic and epiphytic green and blue-green algae, were usually well represented on artificial substrates (Cattaneo \& Amireault 1992). In the case of A. acronicus, a less selective feeder, the energy absorbed by adults eating periphyton was sufficient to meet the energy requirements of reproducing individuals of medium size, but not for the largest snails. However, by eating an algae-detritus complex, the snails consume an excess of the computed requirements in all cases. Suggestions as to how this might work can be found in a study using radiotracers to differentiate grazing by Physella virgata (Gould, 1855) (Carman \& Guckert 1994). ${ }^{3} \mathrm{H}$-amino acids and ${ }^{14} \mathrm{C}$ bicarbonate labels on the bacterial and algal components of periphyton showed that absorption efficiency was greater in snails grazing live periphyton with ${ }^{3} \mathrm{H}$ available as abiotically adsorbed and fixed into bacterial proteins $(50 \%)$ than in snails consuming algae (32\%).

Data on production of studied species calculated with von Bertalanffy's growth model demonstrated that the observed biomass of local populations and daily production are provided not only by potentialities inherent in growth and reproduction but also by food resources (Fig. 8). Secondary production of a population of Anisus acronicus in dry weight per season (Table 2) 
Table 2. Anisus contortus and A. acronicus. Density, biomass (B), mean weight $\left(W_{\text {av }}\right)$, growth rate $\left(C_{W}\right)$ and production $(P)$ of snail populations at 2 sites. $C_{W}$ is a specific growth rate determined from Eq. (4). $P$ was recalculated into dry weight $\left(\mathrm{mg} \mathrm{m}^{-2}\right.$ season $\left.^{-1}\right)$ by using the proportion of dry weight/wet weight $=20 \%$ (authors' pers. obs.). In general, the proportion of freshwater snails depends on species and varies $\sim 15$ to $35 \%$. The season was considered to be $4 \mathrm{mo}$

\begin{tabular}{|lccccccc|}
\hline Site & $\begin{array}{c}\text { Density } \\
\left(\text { ind. } \mathrm{m}^{-2}\right)\end{array}$ & $\begin{array}{c}B \\
\left(\mathrm{mg} \mathrm{m}^{-2}\right)\end{array}$ & $\begin{array}{c}W_{\mathrm{av}} \\
(\mathrm{mg})\end{array}$ & $\begin{array}{c}C_{W} \\
\left(\mathrm{~d}^{-1}\right)\end{array}$ & $\begin{array}{c}P \\
\left(\mathrm{mg} \mathrm{m}^{-2} \mathrm{mo}^{-1}\right)\end{array}$ & $\begin{array}{c}P / B \\
\left(\mathrm{mo}^{-1}\right)\end{array}$ & $\begin{array}{c}P \\
\left(\mathrm{season}^{-1}\right)\end{array}$ \\
\hline \multicolumn{2}{l}{ A. contortus } & & & & & & \\
1 & 52 & 675.8 & 13.0 & 0.028 & 577 & 0.9 & 461 \\
2 & 120 & 891.6 & 7.4 & 0.052 & 1404 & 1.6 & 1123 \\
\multicolumn{2}{l}{$\begin{array}{l}\text { A acronicus } \\
1\end{array}$} & & & & & & \\
2 & 118 & 3995 & 33.9 & 0.016 & 1919 & 0.5 & 1535 \\
& 64 & 2285 & 35.7 & 0.015 & 1033 & 0.5 & 826 \\
\hline
\end{tabular}

was used to compare it with production of other pulmonate and prosobranch freshwater snails with semelparous life cycles.

For subarctic species such as Anisus contortus and $A$. acronicus, the estimation of turnover coefficients $P / B$ per growth and reproductive season $(\sim 120$ to $150 \mathrm{~d})$ is more correct than extrapolation of $P / B$ to an annual period, when freshwater bodies are frequently covered by ice and snails are inactive. Similar values for annual productions were determined for A. rotundatus (Poiret 1801) (1192 mg dry weight $\mathrm{m}^{-2} \mathrm{yr}^{-1}$ ) and Physa fontinalis (Linnaeus, 1758) (846.3 mg dry weight $\mathrm{m}^{-2} \mathrm{yr}^{-1}$ ) (Caquet 1993). For the caenogastropod Bithynia graeca, production assessed by a sizefrequency method was $86.8 \mathrm{~g}$ dry weight $\mathrm{m}^{-2}$ (Eleutheriadis \& Lazaridou-Dimitriadou 2001). This indicates a similarity in production if we recall that $B$. graeca has a short turnover time $(77.9 \mathrm{~d})$ and high $P / B$ (4.7), which is often observed in species from middle and low latitudes.

Comparison of our results with other studies indicates that there are commonalities for gastropods; the main factors determining rate of consumption are mass of animal and quality of food, independent of higher taxonomic membership. A study of the Bithynia graeca consumption of aufwuchs (Eleutheriadis \& LazaridouDimitriadou 1996) showed that its specific consumption rate is very similar to that of Anisus contortus and A. acronicus (Fig. 6). The reported data on B. graeca mass and consumption rate were presented in different units, in mg dry weight and mg aufwuchs per $g$ live weight, respectively. Therefore, we recalculated our data, estimating that epiphyte energetic content of $\sim 5 \mathrm{~J} \mathrm{mg}^{-1}$ and the index of dry weight/wet weight of a snail is approximately $30 \%$. We also were able to make a rough comparison of our results with those from a study of another grazer on epiphytic algae, Potamopyrgus antipodarum (James et al. 2000). Unfortunately, the weight data for $P$. antipodarum in that experiment were not represented, so a direct comparison with our data was not possible; however, we used an available datum on grazing rate of epiphyton of $\sim 18 \mu \mathrm{g}$ $\mathrm{mg}^{-1}$ snail $\mathrm{h}^{-1}$ (derived from James et al. 2000, their Fig. 3) to estimate the $P$. antipodarum in the units shown in Fig. 6 (in this case we assumed $1 \mathrm{mg}$ fresh algae $\times 4.2 \mathrm{~J}$ and dry weight/wet weight $=30 \%$ ). The pattern shown in Fig. 6, while preliminary, indicates similarities across higher taxa.

Our experimental measures assessed the relationship between absorbed energy and generative growth and reproduction. We were not able to assess all the sources of energetic requirements. For example, the production of mucus is likely to be energetically important: energy loss with mucus can be comparable with loss due to respiration (Peck et al. 1987). Furthermore, there are additional expenditures for movement and metabolism linked with temperature increase, predator avoidance and parasite rejection. Although our focal species both consumed detritus in combination with algae, they demonstrate fine-scale differences in their food consumption and thus in trophic niches. Their substrate preferences, movement patterns, sizes and metabolic demands may provide each species a different opportunity and advantage in consumption of this preferred food. Anisus acronicus preferred bottom substrates for feeding and spawning, and combined consumption of detritus with epilithic algae. A. contortus lived on submerged macrophytes where it deposited egg masses and consumed periphyton to a larger degree, not avoiding detritus with bacteria.

The present study indicates how small-scale differences are present between 2 species of pulmonate snails that co-exist in large numbers in an oligotrophic, boreal-subarctic lake system. We expect that these differences are not only important in proximal coexistence, but also present alternatives for surviving longer term changes in the lake's productivity and habitat types. We hope the present study will provide the foundation for predicting species dynamics in sensitive freshwater systems at a time of increasingly certain rapid climate change.

Acknowledgements. We thank Dr. V. Berger and Dr. A. Sukhotin, Director of the Biological Station at the White Sea, for the opportunity to use laboratory facilities for this research. We thank 3 anonymous reviewers who provided constructive comments on this work. This work was supported by the Russian Fund for Basic Investigations (No. 1993.2008.4). 


\section{LITERATURE CITED}

Alimov AF (1989) An introduction to production hydrobiology. Gydrometeoizdat, Leningrad

Amouroux JM (1984) Preliminary study on the consumption of dissolved organic matter (exudates) of bacteria and phytoplankton by the marine bivalve Venus verrucosa. Mar Biol 82:109-112

Basset A (1997) Mechanisms relating biomass concentration in individuals to interspecific resource competition. Oikos 78:31-36

Brendelberger H (1997) Contrasting feeding strategies of two freshwater gastropods, Radix peregra (Lymnaeidae) and Bithynia tentaculata (Bithyniidae). Arch Hydrobiol 140: $1-21$

Calow P (1975) On the nature and possible utility of epilithic detritus. Hydrobiologia 46:181-189

Cammen LM (1979) Ingestion rate: an empirical model for aquatic deposit feeders and detritivores. Oecologia 44: $303-310$

Caquet T (1993) Comparative life-cycle, biomass and secondary production of three sympatric freshwater gastropod species. J Molluscan Stud 59:43-50

Carman KR, Guckert JB (1994) Radiotracer determination of ingestion and assimilation of periphytic algae, bacteria, and adsorbed amino acids by snails. J N Am Benthol Soc 13:80-88

Cattaneo A, Amireault MC (1992) How artificial are artificial substrata for periphyton? J N Am Benthol Soc 11:244-256

$>$ De Francesco CG, Isla FI (2004) The life cycle and growth of Heleobia australis (D'Orbigny, 1835) and H. conexa (Gaillard, 1974) (Gastropoda: Rissooidea) in Mar Chiquita coastal lagoon (Argentina). J Molluscan Stud 70:173-178

Den Boer PJ (1985) Exclusion, competition or coexistence? A question of testing the right hypotheses. Z Zool Syst Evol 23:259-274

Edmondson WT, Winberg GG (eds) (1971) A manual of methods for assessment of secondary productivity in fresh waters. IBP Handbook No. 17. Blackwell, Oxford

Eleutheriadis N, Lazaridou-Dimitriadou M (1996) Nutritional budget in the freshwater snail Bithynia graeca (Gastropoda, Bithynidae). J Molluscan Stud 62:177-184

Eleutheriadis N, Lazaridou-Dimitriadou M (2001) The life cycle, population dynamics, growth and secondary production of Bithynia graeca (Westerlund, 1879) (Gastropoda) in Lake Kerkini, Northern Greece. J Molluscan Stud 67:319-328

Fletcher WJ, Creese RG (1985) Competitive interactions between co-occurring herbivorous gastropods. Mar Biol 86: 183-192

Hall RO Jr, Meyer JL (1998) The trophic significance of bacteria in a detritus-based stream food web. Ecology 79: $1995-2012$

Hines A (1982) Coexistence in a kelp forest: size, population dynamics, and resource partitioning in a guild of spider crabs (Brachyura, Majidae). Ecol Monogr 52:179-198

> James MR, Hawes I, Weatherhead M, Stanger C, Gibbs M (2000) Carbon flow in the littoral food web of an oligotrophic lake. Hydrobiologia 441:93-106

Lombardo P, Cooke GD (2002) Consumption and preference

Editorial responsibility: Victor Benno Meyer-Rochow, Bremen, Germany of selected food types by two freshwater gastropod species. Arch Hydrobiol 155:667-685

Lombardo P, Cooke GD (2004) Resource use and partitioning by two co-occurring freshwater gastropod species. Arch Hydrobiol 159:229-251

McIntyre PB, Michel E, France K, Rivers A, Hakizimana P, Cohen AS (2005) Individual- and assemblage-level effects of anthropogenic sedimentation on snails in Lake Tanganyika. Conserv Biol 19:171-181

Økland J (1990) Lakes and snails. Universal Book Services/ Dr. W. Backhuys, Oegstgeest

Ostapenja AP (1965) Completeness of oxidation of organic matter in aquatic invertebrates by the method of bichromatic oxidation. Dokl Akad Nauk BSSR 9:273-276 (in Russian with English Abstract)

Peck LS, Culley MB, Helm MM (1987) A laboratory energy budget for the ormer Haliotis tuberculata L. J Exp Mar Biol Ecol 106:103-123

Quiring DT, McNeil JN (1984) Exploitation and interference intraspecific larval competition in the dipteran leaf-miner, Agromyza frontella (Rondani). Can J Zool 62:421-427

Schmitt RJ (1996) Exploitation competition in mobile grazers: trade-offs in use of a limited resource. Ecology 77:408-425

Schoener TW (1974) Resource partitioning in ecological communities. Science 185:27-39

Starobogatov YI (1977) Diagnostic key of freshwater invertebrates of the European part of the USSR. Gidrometeoizdat, Leningrad

Stearns SC (1992) The evolution of life histories. Oxford University Press, Oxford

Tilman D (1994) Competition and biodiversity in spatially structured habitats. Ecology 75:2-16

Townsend CR, Hildrew AG (1979) Foraging strategies and co-existence in a seasonal environment. Oecologia 38: 231-234

> Underwood AJ (1984) Vertical and seasonal patterns in competition for microalgae between intertidal gastropods. Oecologia 64:211-222

- Underwood AJ, Thomas JD (1990) Grazing interactions between pulmonate snails and epiphytic algae and bacteria. Freshw Biol 23:505-522

Walford LA (1946) A new graphic method of describing growth of animals. Biol Bull 90:141-147

Wenngren J, Ólafsson E (2002) Intraspecific competition for food within and between year classes in the depositfeeding amphipod Monoporeia affinis - the cause of population fluctuations? Mar Ecol Prog Ser 240:205-213

- Williams GA (1994) Variation in populations of Littorina obtusata and L. mariae (Gastropoda) in the Severn Estuary. Biol J Linn Soc 51:189-198

Wullschleger EB, Jokela J (2002) Morphological plasticity and divergence in life-history traits between two closely related freshwater snails, Lymnaea ovata and Lymnaea peregra. J Molluscan Stud 68:1-5

Yu OH, Sun HL, Shirayama Y (2003) Feeding ecology of three amphipod species Synchelidium lenorostralum, S. trioostegitum and Gitanopsis japonica in the surfzone of a sandy shore. Mar Ecol Prog Ser 258:189-199

Zhadin VI (1952) Molluscs of fresh and saltish waters of the USSR. Proc Acad Sci USSR 36

Submitted: October 31, 2008; Accepted: March 18, 2009

Proofs received from author(s): April 29, 2009 